\section{SOI: $1.1 /$ TAS DOI: $10.15863 /$ TAS International Scientific Journal Theoretical \& Applied Science}

\author{
p-ISSN: 2308-4944 (print) e-ISSN: 2409-0085 (online) \\ Year: 2015 Issue: 12 Volume: 32 \\ Published: $30.12 .2015 \quad$ http://T-Science.org
}

Dildora Madaminovna Khoshimova

Doctor of philology, Namangan Institute of Engineering and Technology, Uzbekistan dxoshimova@mail.ru

SECTION 29. Literatute. Folklore. Translation Studies.

\title{
SCIENTIFIC TERMS AND COMPARATIVE STYLE IN "BABURNAME" BY Z.M.BABUR
}

\author{
Abstract: The article is devoted to scientific terms and comparative descriptions which used in "Baburname". \\ It was informed that the information was given in various themes by comparison style and reveal clearly artistic \\ language peculiarities for his prose genres also used the opportunities richness of lexical features. \\ Key words: comparative style, literary-artistic works, scientific term, comparative analysis, astronomical units \\ of measurement areas \\ Language: English \\ Citation: Khoshimova DM (2015) SCIENTIFIC TERMS AND COMPARATIVE STYLE IN \\ "BABURNAME" BY Z.M.BABUR. ISJ Theoretical \& Applied Science 12 (32): 55-57. \\ Soi: http://s-o-i.org/1.1/TAS-12-32-10 Doi: crossef http://dx.doi.org/10.15863/TAS.2015.12.32.10
}

Zakhritdin Muhammad Babur - a major public figure, the founder of the dynasty of Babur, the famous commander, historian, psychologist, poet, translator, ethnographer and geographer has left its mark in history as a brilliant scientist marks. During his activity that he wanted to expand and strengthen economic, political and cultural relations with Movarounnahr, Khorasan, India and Russia. In particular, the diplomatic relations were established by state of baburids, it was continued with his name after his death who academic V.V. Bartold was said that in his book "History studying of Orient in Russia and Europe"[1.p.174].

Babur's great literary is heritage treasure. His poetic Divan[4], "Baburname", "Risolai Aruz", "Xatti Baburiy", "Mubayyin"[5] and also "Musiqa ilmi" and "Harb ishi" have not found yet, as well as his numerous scientific and literary-artistic works were played an important role in development of world literature, arts and culture. There were information about the poems were written in Indian language by Babur when he was in India[10. P.32].

"Baburname" has been translated into more than 30 languages of the world that the complete and incomplete. The first time was published in 1826 who accomplished by the British Orientalists J.Leyden, U.Erskine [9]. The translation by J.Leyden and U.Erskine in 1921 by Oxford University Press has published many volumes for the second time. The foreword was written by Dublin University professor L.King for publication and provides information about the translations, omissions publications, copies of the manuscript funds in the world that the English edition of the option was edited again[6]. The second English translation of the work associated with the name of the scholar Annette Beverij[2]. In 1900, the famous British Orientalist H.Beverij received a copy of "Baburname" in Hyderabad and announced it as facsimile in London in 1905. "Baburname" was translated by W. Thackston for the third time in 1996 [8].

Babur's diversity comparison style, volume of the subject is delighted the people. The author described the extraordinary skills of this area in "Baburname". It was informed that the information was given in various themes by comparison style and reveal clearly artistic language peculiarities for his prose genres also used the opportunities richness of lexical features. We saw that linguist Babur found surprisingly a solution in all the examples by Indian, Persian, Arab, Turkic languages comparative analysis of the issues.

It was very difficult to adapt the concepts to Indian calendar procedures for Babur because he used to terms in Movarounnahr and Khorasan Islamic seasons, years, months, days to the calendar. Writer had faced a lot of difficulties to compare each of them and as a result we will be witness qualified as an expert perspectives.

We paid attention to Babur's comparative analysis of Islamic terms and between Indian seasons distribution. It is so accurate, balanced in 
comparative analysis and Persian, Turkish Alternatives astronomical seasons of Indian terms were clearly marked for reader of "Baburname" don't distract, we feel who the person carrying out a comparative research: "Yana ul viloyatlarda to'tr fasltur. Hindustonda uch fasl bo'lur: to'tr oyi yozdur, to'rt oyi pashakaal, to'rt oyi qish. Oylarning ibtidosi hiloliy oylarning istiqbolidindur. Har uch yilda bir oyni pashakaal oylarig'a ziyoda qilurlar. Yana uch yilda qish oylarig'a ziyoda qilurlar. Yana uch yilda yoz oylarig'a. Bularning kabisasi budur'[3. P.207] (In our country there are four seasons, but in Hindustan there are three: four months of summer, four of monsoon, and four of winter. The months begin with the crescent moon in opposition. Every three years one month is added to the monsoon months, then three years later a month is added to the winter months, then three years later a month is added to the summer months. This is their intercalation).

Let us consider to this aspect of the text. Mathematical, astronomical aspects were not recorded separately in Babur's comparative method. They collaborated to one another and completed to each other. In Muslim astronomical calendar that it comes a time in four years, it calls cabica year (more than once a day in the month of February every four years, 29 days) Babur compared with India seasons in the calendar, given a clear interpretation, such as scientific points of view are delivered to the reader and also shows how widely Babur's thinking.

It is quite a difficult situation which terms of units of time in India for Babur, we witness that he carried out closely monitored in this matter in "Baburname". To distract of citizens that especially Indians' uncertainty time units for a night- day was attracted the writer's attention. First of all, this is very necessary for the reign of Emperor Babur in India. Meanwhile, "pahar", "pos" "gariy", "gariyaliy", "gariyal" in Indians and other terms were determined the exact time of astronomic, Babur felt to certain degrees of confusion of the marks in this time and did its reform.

Babur continued thinking about his inventions to clarify the above issues, emphasizing that need to put an end to this issue, conducted an experiment on this, he said to open the way for reforms in the field. Now this movement is not a simple theoretical ideas, perhaps it's practical experience.

Babur's comparative analysis was tradition by Indian people through the centuries, but it's examples for the unit time is not still correct explained that he was pleased to don't hide to given a good result by the following on his reforming way. King Babur's positive attribute should be mentioned because he called local knowledgeable persons to "to advice" for taking this experience. Babur detailed description unit of time for a night and day in India.
After defining the detailed description, Babur considered the error of this time in the country and he offers his invention a new option. It was shown which Babur's invention of life even the most convenience for the common people in this comparative analysis, this identification was carried out by comparison style: "Burun gariyaliylar kechakunduzda pahar tuganganda-o'q pahar alomatini qoqarlar edi. Kechalar uyqudin uyg'ong'onlarg'a uch gariy yo to'rt gariyning qoqqon uni kelsa edi, ma'lum bo'lmas edikim, ikkinchi paharmudur, yo uchunchi paharmudur. Men buyurdumkim, kecha gariylarini va bulutluq kunduz gariylarini qoqqondin so'ng, paharning alomatini qoqqaylar, masalan, kechaning avvalg'i paharidin uch gariy qoqqondin so'ng, paharning alomatini qoqqaylar, masalan, kechaning avvalg'i paharidin uch gariy qoqqondin so'ng, darang qilib, paharning alomatini yana bir ham qoqqaylar, ya'ni ma'lum bo'lg'aykim, bu uch gariy avvalg'i pahardindur. Kechaning uchunchi paharidin to'rt gariy qoqqondin so'ng, darang qilib, paharning alomatini uch qoqqaylar, ya'ni ma'lum bo'lg'aykim, bu to'rt gariy uchunchi pahadindur, heyli yaxshi bo'ldi. Kecha har vaqt uyg'ong'onda gariy uni kelsa, mushaxxas bo'ladurkim, qaysi pahardin necha gariy bo'lubtur "[3. P.207-208] (They used to announce the new watches by striking only when the previous ones were finished, but people who woke up during the night and heard the sound of three or four gharis being struck did not know whether it was for the second or the third watch. I therefore ordered them to herald the watches of the night and cloudy days by striking only after they had struck the ghari first. For example, after striking the third ghari of the first watch of the night, they would pause and announce the watch by striking once more, so it was obvious that it was the third ghari of the first watch. After striking the fourth ghari of the third watch of the night, they would pause before striking three times. It was a great idea. Whenever people woke up at night and heard the sound of the ghariyal, they knew which watch and which ghari it was).

Above if Babur measure with a specific method a time units of Movarounnahr to the times of day and night of India, duration of terms are defined, more precisely he compared to "gariyyalar" belong to Indian terms of time which Islamic terms and his invention of units of time, he took time to explore two regional unit of time in the following paragraph and appropriate conclusions. Babur conduct the research with careful to this analytical analysis, found clearly evidence and did long-term experiments, compared with the time, he wrote a serious maintain their accounting in "Baburname": "Yana har gariyni oltmish bo'lubturlar, har birini pal debturlarkim, bir kecha-kunduz uch ming olti yuz pal bo'lg'ay. Yana har bir pal miqdorini oltmish qatla ko'zni yumub-ochquncha debturlarkim, kecha- 


\begin{tabular}{l|lrl|l|ll} 
& ISRA (India) & $=\mathbf{1 . 3 4 4}$ & SIS (USA) & $=\mathbf{0 . 9 1 2}$ & ICV (Poland) & $=\mathbf{6 . 6 3 0}$ \\
Impact Factor: & ISI (Dubai, UAE) $=\mathbf{0 . 8 2 9}$ & PUHL (Russia) $=\mathbf{0 . 1 7 9}$ & PIF (India) & $=\mathbf{1 . 9 4 0}$ \\
& GIF (Australia) & $\mathbf{0 . 5 6 4}$ & ESJI (KZ) & $=1.042$ & & \\
& JIF & $\mathbf{1 . 5 0 0}$ & SJIF (Morocco) $=\mathbf{2 . 0 3 1}$ & &
\end{tabular}

кундуз ikki yuz o'n olti ming ko'zni yumubochquncha bo'lg'ay. Bir palni tajriba qilildi, taqriyban sekkiz qatla "qulhuvallo"ni "bismillo" bila o'qug'uncha bo'ldukim, kecha-kunduz yigirma sekkiz ming sekkiz yuz "qulhuvallo"ni "bismillo" bila o'qug'ucha bo'lg'ay"[3. P.208] (Every ghari is divided into sixty parts, each of which is called a pal, so that a day and night contain 3,600 pals. They say that a pal lasts the time it takes to shut and open the eyes sixty times, so during a day and a night you could shut your eyes and open them 216,000 times. By experiment it has been determined that a pal is approximately the length of time it takes to say qulhuwa'llah and bismillah eight times, so during a day and night you could say qulhuwa'llah and bismillah 28, 800 times).

We have witnessed that Babur deep draw conclusions to each issue seriously, comparable units of Movarounnahr, India's units of time belong to other spheres of social life on the weight of the unit mathematical numbers and the length of time, with astronomical units of measurement areas on the comparative analysis of the relationship between the numbers of terms. As well as possible, Babur tried with these regulations in this sphere Movarounnahr scientific-potential of the Indians and convenient options to make this country a certain degree of civilization in its attempt to exert influence.

\section{References:}

1. Bartold VV (1925) "Evropa va Rossiyada Sharqni o'rganish tarixi”. Toshkent: Fan, 1925.

2. Beveridge AS (1970) The Babur-nama in English (Memoirs of Babur), Translated from the original Turki Text of Zahiru'ddin Muhammad Babur Padshah Ghazi by Annette, Susannah Beveridge, 2 Vols -London, -1922; Repr, in one Volume, London, -1969; New Delhi, -1970; Lahore.

3. Zahiriddin Muhammad Bobur (2002) "Boburnoma" Toshkent: "Sharq", -2002.

4. (1994) Bobur. Devon. Nashrga tayerlovchi A.Abduғafurov. - T.: Fan 1994.

5. (2000) Bobur. Mubayyin. Nashrga tayerlovchi S.Xasanov. -T.: Khalk meros 2000.
6. Ibrohimov A (2000) Bobunoma-buyuk asar. Toshkent: 2000 .

7. (1978) O'zbek adabiyoti tarixi. 11-jild. T: Fan, 1978.

8. (1996) The Baburnama. Memoirs of Babur, Prince and Emperor, Translated, edited, and, annotated by Wheeler M., Thackston, New York \& Oxford, -1996.

9. Leyden J, Erskine W (1826) Memoirs of Zahired-din Muhammed Babur, Emperor of Hindustan.- Edinburg -1826.

10. Hasan Beg (2008) "Boburning adabiy merosi". Toshkent: Fan, 2008. 32 p. 